\title{
Cytotoxic Activities Against Ehrlich Carcinoma and Human K562 Leukaemia of Alkaloids and Flavonoid from Two Solanum Species
}

\author{
Andressa Esteves-Souza, ${ }^{a}$ Tânia M. Sarmento da Silva, ${ }^{a}$ Cássia C. Fernandes Alves, ${ }^{a}$ \\ Mário G. de Carvalho, ${ }^{a}$ Raimundo Braz-Filho ${ }^{b}$ and Aurea Echevarria ${ }^{*, a}$ \\ ${ }^{a}$ Departamento de Química, Instituto de Ciências Exatas, Universidade Federal Rural do Rio de Janeiro, 23851-970 \\ Seropédica - RJ, Brazil \\ ${ }^{b}$ Setor de Química de Produtos Naturais - LCQUI - CCT, Universidade Estadual Norte Fluminense, 28015-620 \\ Campos dos Goitacazes - RJ, Brazil
}

\begin{abstract}
Diversas espécies do gênero Solanum apresentam glicoalcalóides e flavonóides com grande variedade de atividades biológicas. O flavonóide tiliroside (1), uma fração rica em glicoalcalóides denominada GB e o glicoalcalóide solasonina (2) foram obtidos dos tricomas de galhos jovens e frutos de Solanum crinitum Lam e o alcalóide estereoidal solasodina (3), extraído das partes aéreas de $S$. jabrense Agra \& M. Nee, tiveram sua atividade citotóxica avaliada frente a células do carcinoma de Ehrlich e da leucemia humana K562. O efeito antiproliferativo destas substâncias mostrou comportamento dose-dependente após avaliação através do método do MTT, para ambos os casos. Os resultados indicaram atividade citotóxica para $\mathbf{1}$, GB e 2 , com $\mathrm{IC}_{50}=69,50 \mu \mathrm{M}, 19,5 \mu \mathrm{g} \mathrm{mL}^{-1} \mathrm{e}$ $74,20 \mu \mathrm{M}$, respectivamente, quando ensaiadas frente ao carcinoma de Ehrlich, e $\mathrm{IC}_{50}=118,40 \mu \mathrm{M}$, $13,65 \mu \mathrm{g} \mathrm{mL}^{-1}, 60,35 \mu \mathrm{M} \mathrm{e} \mathrm{76,92} \mu \mathrm{M}$ para $\mathbf{1}, \mathrm{GB}, 2$ e $\mathbf{2 a}$ (derivado peracetilado da solasonina) frente a leucemia K562. A baixa atividade da aglicona solasodina (3) indicou a importância da presença dos açúcares na estrutura do glicoalcalóide e permitiu postular a substância $\mathbf{2}$, presente na fração rica em glicoalcalóides (GB), como um dos principios ativos. Além disso, os resultados mostraram a possibilidade de biomonitoramento através do ensaio do MTT na busca de metabólitos com atividade citotóxica.
\end{abstract}

Steroidal alkaloids, flavonoids and their glycosides occurring in numerous species of Solanum genus are known to possess a variety of biological activities. The flavonoid tiriloside (1), a rich in glycoalkaloids total fraction named GB and the glycoalkaloid solasonine (2) isolated from thricomes of young branches and fruits from Solanum crinitum Lam, and the aglycone solasodine (3) isolated from Solanum jabrense Agra \& M. Nee, were assayed against murine Ehrlich carcinoma and human K562 leukaemia cultured cells. The exposure in vitro of these cancer cells to these products resulted in a dose-dependent growth inhibition evaluated by the MTT method. The results indicated significant cytotoxic activities with $\mathrm{IC}_{50}=69.50 \mu \mathrm{M}, 19.5 \mu \mathrm{g} \mathrm{mL}^{-1}$, and $74.20 \mu \mathrm{M}$ for 1 , GB and 2, respectively, against Ehrlich carcinoma, and $\mathrm{IC}_{50}=186.50 \mu \mathrm{M}, 13.65 \mu \mathrm{g} \mathrm{mL}^{-1}$ and $76.92 \mu \mathrm{M}$, for 1, GB, 2 and 2a, respectively, against K562 leukaemia cells. The low activity of the aglycone 3 indicates that the role of the sugar moiety is very important in the cytotoxic activity of glycoalkaloid solsonine. The cytotoxic activity revealed by the GB fraction may be attributed to the presence of $\mathbf{2}$. Additionally, these results show the viability of the MTT assay for monitoring phytochemical bioactive compounds.

Keywords: Solanaceae, Solanum crinitum, Solanum jabrense, citotoxicity, Ehrlich carcinoma, human K562 leukaemia, tiliroside, glycoalkaloids

\section{Introduction}

Pharmacological and chemical investigations of medicinal plants have provided important advances in the therapeutic approach to several pathologies, as well as

\footnotetext{
*e-mail: echevarr@ufrrj.br
}

extremely useful tools for the theoretical study of physiology and pharmacology. ${ }^{1}$ A number of medicinal plants containing flavonoids and alkaloids are used in natural medicine and are known to contain important therapeutic agents. For example, Ginkgo biloba, Ginkgoaceae family, used to prevent coronary artery disease, ${ }^{2}$ Garcinia kola, Guttiferae family, component of 
Kolaviron for the treatment of various diseases, including hepatitis and laryngitis, ${ }^{3}$ and several Leguminosae plants containing isoflavonoids with potent estrogenic activity. ${ }^{4}$

Many plants in the Solanaceae family accumulate steroidal alkaloids based on a $\mathrm{C}_{27}$ cholestane skeleton, e.g. solasodine and tomatidine. These compounds are essentially nitrogen analogues of steroidal saponins, and they are usually present as glycosides which have surface activity and hemolytic properties as do the saponins. ${ }^{5}$ Steroidal alkaloids and their glycosides occurring in numerous species of Solanum genus are known to possess a variety of biological activities, including antifungal, ${ }^{6,7}$ molluscicidal, ${ }^{8}$ teratogenic, and embryotoxic. ${ }^{9}$ Preparations containing solasodine glycosides are currently employed for the treatment of certain skin cancers. ${ }^{10}$

Flavonoids are special plant metabolites, present in all terrestrial vascular plants. Flavonoids are chemically defined as substances composed of a common $\mathrm{C}_{6}-\mathrm{C}_{3}-\mathrm{C}_{6}$ skeleton, with one or more hydroxyl groups and others substituents. A high proportion of flavonoids occur naturally as water-soluble glycosides. Considerable quantities of flavonoids are consumed daily in our vegetable diet, and some are particularly beneficial, acting as antioxidants and giving protection against cardiovascular disease and certain types of cancer. ${ }^{5}$ The pharmacological effects of flavonoids in animals are diverse: antiviral, antimicrobial, anti-inflammatory and antihepatotoxic. ${ }^{11,12}$ Moreover, many studies have suggested that flavonoids exhibit important cancer chemoprevention ${ }^{13-16}$ and anticancer activities. ${ }^{17-19}$

Focusing on the anti-cancer properties of chemical constituents from Brazilian plants we have assayed the cytotoxic activities against Ehrlich carcinoma and human K562 leukaemia cells of a glicoalkaloid fraction (GB), the flavonoid tiliroside (1), solasonine (2) and peracethyl solasonine (2a) from Solanum crinitum Lam and the aglicone solasodine (3) from $S$. jabrense. We report here our latest results.

\section{Experimental}

\section{Plant material, extraction and isolation}

Tiriloside (1). Aerial parts of Solanum crinitum Lam were collected in Seropédica (Rio de Janeiro, Brazil) and a voucher specimen (Sarmento s. n., JPB-28000), was deposited in the Lauro Pires Xavier Herbarium of Universidade Federal da Paraíba (Paraíba, Brazil). The trichomes of $S$. crinitum $(9.7 \mathrm{~g})$ were isolated by mildly scratching the young leaves with a glass slide and subsequent extraction with $\mathrm{CHCl}_{3}$ in an ultrasound bath.
The extract was concentrated under vacuum and the residue was submitted to precipitation with $\mathrm{MeOH}$. The filtrate extract was separated by Sephadex LH-20 column chromatography using $\mathrm{MeOH}$ as eluent to furnish tiriloside (1, $30 \mathrm{mg}, 0.31 \%$ yield). The structure of tiriloside (1) was identified on the basis of NMR data, including $1 \mathrm{D}$ and 2D experiments.

Glycoalkaloid fraction $(G B)$. The fresh fruits of $S$. crinitum (2600 g) were collected in the Universidade Federal Rural do Rio de Janeiro (Seropédica, Rio de Janeiro, Brazil). The extraction was realized by maceration with $\mathrm{EtOH}-\mathrm{H}_{2} \mathrm{O}-\mathrm{AcOH}(90: 8: 2)$ and filtration. The process was repeated several times, and the combined filtrates, after concentration in vacuum, were dissolved in $\mathrm{H}_{2} \mathrm{O}-\mathrm{AcOH}$ (9:1), filtered over Celite, treated with $\mathrm{NH}_{4} \mathrm{OH}$ to $\mathrm{pH}$ 9-10 and an enriched total glycoalkaloid fraction was precipitated (96 g, 3.7\% yield), and collected by filtration.

Solasonine (2). A part of the enriched total glycoalkaloid fraction $(92 \mathrm{~g})$ was chromatographed over Sephadex LH-20 column using methanol as eluent, and various fractions were collected. After crystallization with acetone, glycoalkaloid 2 (300 mg, $0.33 \%$ yield) was isolated and its structure established on the basis of NMR data.

Peracetyl solasonine (2a). Solasonine 2 (80 mg), was dissolved in pyridine $(2 \mathrm{~mL})$ and treated overnight with acetic anhydride $(2 \mathrm{~mL})$ at room temperature. Ice was added to the reaction mixture and it was immediately extracted with ethyl acetate. The ethyl acetate layer was dried over $\mathrm{MgSO}_{4}$ and evaporated to afford $\mathbf{2 a}$ in quantitative yield. The structure of $\mathbf{2 a}$ was established using NMR data.

Solasodine (3). Solanum jabrense Agra \& M. Nee was collected in the Pico do Jabre, Maturéia, Paraíba, Brazil. A voucher specimen (M. F. Agra eta. 5257) was deposited in the Lauro Pires Xavier Herbarium of Universidade Federal da Paraíba (Paraíba, Brazil). The aerial parts from Solanum jabrense (1400 g) were extracted with ethanol and partitioned with hexane, chloroform and methanol. The methanol fraction was chromatographed on a silica gel column and one of the fractions (\# 6) was treated with acetyl chloride, dissolved in $\mathrm{MeOH}-\mathrm{H}_{2} \mathrm{O}$ (1:1) and extracted with ethyl acetate. The residue obtained was filtered through Sephadex LH-20 (with $\mathrm{CHCl}_{3}: \mathrm{MeOH}, 1: 1$ ). The fractions obtained were recrystallized from methanol to yield alkaloid 3 (15 mg, $0.001 \%$ yield, $201-203{ }^{\circ} \mathrm{C}$, lit. $\left.{ }^{22} 201-202{ }^{\circ} \mathrm{C}\right)$.

\section{NMR data}

${ }^{1} \mathrm{H}$ and ${ }^{13} \mathrm{C}$-NMR spectra were determined on a Bruker DRX-500 spectrometer $\left({ }^{1} \mathrm{H}\right.$ : $500 \mathrm{MHz}$ and $\left.{ }^{13} \mathrm{C}: 125 \mathrm{MHz}\right)$, 
in $\mathrm{CDCl}_{3}$ or DMSO- $d_{6}$ solutions, using TMS as internal standard.

\section{Cytotoxic assays}

Cell culture. Ehrlich carcinoma cell cultures were started from mice ascites with at least one passage in vitro prior to use. Dilution series of cytotoxic drugs in DMSO at final concentration of $0.3 \%(\mathrm{v} / \mathrm{v})$ were prepared in triplicate steps in 96-culture well plates, and $1 \times 10^{6}$ tumour cells (Ehrlich carcinoma or K562 leukaemia) were added to cultures in RPMI 1640 complete medium, supplemented with $5 \%$ heat inactivated foetal calf serum, and $0.1 \%$ streptomycin/penicillin, and incubated at $37^{\circ} \mathrm{C}$, in a humidified atmosphere of $5 \% \mathrm{CO}_{2}$ for $48 \mathrm{~h} .{ }^{17}$

MTT assay. Cell viability were also assayed under the same conditions as above in the absence or presence of $\mathbf{1}$, 2, 2a and $\mathbf{3}$ at 200, 100, 50 and $25 \mu \mathrm{M}$, and GB at 25, 12, 6 and $3 \mu \mathrm{g} \mathrm{mL}{ }^{-1}$, using the Mossman assay. ${ }^{20}$ Drug effects were observed after $48 \mathrm{~h}$ of culture incubation. MTT [3(4,5-dimethylthiazol-2-yl)-2,4-dipheniltetrazolium bromide] was added to samples and the absorbance was measured after $3 \mathrm{~h}$. The concentration required to reduce the absorbance by $50 \%\left(\mathrm{IC}_{50}\right)$ in comparison with control were determined. The $\mathrm{IC}_{50}$ values were determined as means of three independent experiments in $\mu \mathrm{M}$ or $\mu \mathrm{g} \mathrm{mL}^{-1}$ with standard deviation in the range of $10-15 \%$.

\section{Results and Discussion}

\section{Isolation and identification of constituents}

The trichomes of the young branches of the Solanum crinitum were extracted with $\mathrm{CHCl}_{3}$ in an ultrasound bath. The solvent was removed under vacuum to yield the residue that was treated with methanol. The filtrate obtained from this treatment was chromatographed on Sephadex LH-20 to provide the glycosilated flavonoid tiliroside (1) in $0.31 \%$ yield. The green fruits of S. crinitum were extracted with $\mathrm{EtOH}-\mathrm{H}_{2} \mathrm{O}-\mathrm{AcOH}(90: 8: 2)$ and the extract was basified with ammonia. The basic residue (GB) on chromatography in a Sephadex LH-20 columm (methanol elution) afforded the glycoalkaloid solasonine (2). The aerial parts from $S$. jabrense were extracted with ethanol and partitioned with hexane, chloroform and methanol. Column chromatography on silica gel of the methanol fraction afforded the alkaloid solasodine (3).

No previous work has been reported on this species.

Comparative analysis of HBBD and DEPT ${ }^{13} \mathrm{C}$ NMR spectra of each natural product ( $\mathbf{1}$ to $\mathbf{3}$ ) was used to identify signals corresponding to quaternary methine, methylene and methyl carbon atoms. The structural identification of these compounds was based on their spectral data, including one bond and multibond ${ }^{1} \mathrm{H}$ and ${ }^{13} \mathrm{C}$ correlations which were obtained by $2 \mathrm{D}$ NMR using HMQC $\left({ }^{1} J_{\mathrm{CH}} 140\right.$ $\mathrm{Hz})$ and $\mathrm{HMBC}\left({ }^{\mathrm{n}} \mathrm{J}_{\mathrm{CH}} 9 \mathrm{~Hz}\right)$ pulse sequences, together with comparison with literature values of ${ }^{1} \mathrm{H}$ and ${ }^{13} \mathrm{C}$ NMR. ${ }^{21-23}$

The comparison of ${ }^{1} \mathrm{H}$ and ${ }^{13} \mathrm{C}$ NMR spectral data of 1 and 6"'-coumarol kaempferol-3-O-glycoside (tiliroside) described in the literature ${ }^{21}$ was used to recognize both as the same compound. This is the first register of flavonoid tiliroside (1) in the Solanum genus.

The structures of the steroidal alkaloids $\mathbf{2}$ and $\mathbf{3}$ were confirmed by comparison of their ${ }^{13} \mathrm{C}$ NMR spectral data with those reported in the literature for solasonine (2) ${ }^{22,23}$ and solasodine (3), ${ }^{23}$ both isolated previously from Solanum khasianum..$^{23}$ The ${ }^{1} \mathrm{H}$ NMR data of the peracetyl derivative 2a were also used during our structural elucidation of 2 .

\section{Cytotoxic activities}

In this work we present the cytotoxic activities of the flavonoid tiliroside (1), the glycoalkaloid rich total fraction GB, the glycoalkaloid solasonine (2) and its acetylated derivative 2a, extracted from Solanum crinitum, and of the aglycone solasodine (3), obtained from $S$. jabrense, against murine Ehrlich carcinoma and human K562 leukaemia cultured cells.

The exposure of in vitro Ehrlich tumour cells to flavonoid 1 resulted in a dose-dependent growth inhibition, evaluated by the MTT assay ${ }^{20}$ after $48 \mathrm{~h}$ of culture. The value of $\mathrm{IC}_{50}=(69.50 \pm 14.90) \mu \mathrm{M}$ indicated a significant cytotoxic activity. However, flavonoid $\mathbf{1}$ was reported as inactive against some human cell lines. ${ }^{26-28}$ Other flavonoids have presented antiproliferative effects against other tumoral cell lines, such as genistein with $\mathrm{IC}_{50}=50 \mu \mathrm{M}$ against breast cancer MCF- $7 ;^{26}$ citrus flavonoids (quercetin, taxifolin, nobiletin, and tangeritin) at $2-8 \mu \mathrm{g} \mathrm{mL}^{-1}$ for $3-7$ days against squamous cell carcinoma HTB $43,{ }^{25}$ among others.

The glycoalkaloid rich fraction GB also presented an antiproliferative effect against Ehrlich carcinoma cells, on $48 \mathrm{~h}$ culture using the Mossman assay, ${ }^{20}$ with $\mathrm{IC}_{50}=(19.5 \pm$ 2.1) $\mu \mathrm{g} \mathrm{mL}^{-1}$. Later, the principal glycoalkaloid of this fraction was isolated and characterized as solasonine (2), which after acetylation furnished 2a. These alkaloids were assayed against Ehrlich carcinoma cells, and the $\mathrm{IC}_{50}$ value was $(74.20 \pm 6.26) \mu \mathrm{M}$ for $\mathbf{2}$, while $2 \mathrm{a}$ was inactive. Furthermore, the aglycone solasodine (3) was tested, under the same conditions showing a small antiproliferative effect $(5 \%$ at $200 \mathrm{mM})$ against Ehrlich carcinoma cells. 


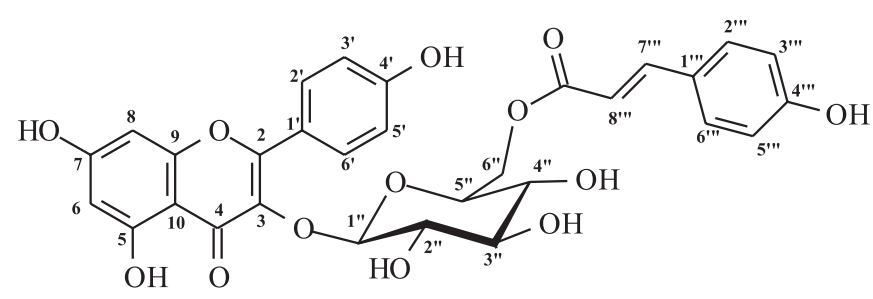

1

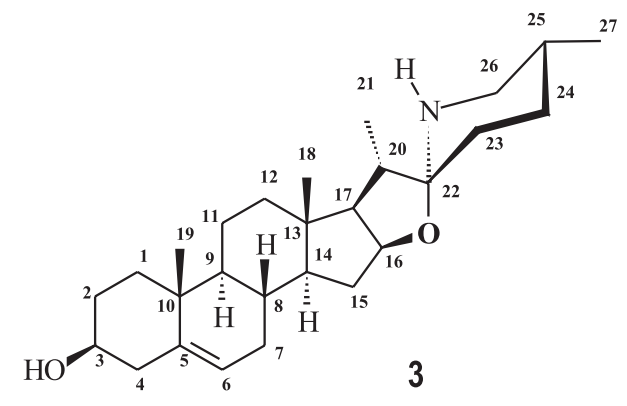$$
\mathrm{H}(2)
$$$$
\mathrm{R}=\mathrm{OAc}(2 \mathrm{a})
$$

The low activity of the aglycone indicates that the role of the sugar moiety is very important. Thus, these results suggested $\mathbf{2}$ as the possible active metabolite in the glycoalkaloid fraction. An increase of lipophylicity in $\mathbf{2 a}$, afforded a reduction of the antiproliferative effect.

Compounds 1, 2, 2a, 3 and GB were also tested for their cytotoxicities against human K562 leukaemia cell line using the Mossman assay, ${ }^{20}$ after $48 \mathrm{~h}$ of cell culture. Among the natural products assayed, 1, 2, 2a and GB showed concentration-dependent growth inhibiting activities on cultured $\mathrm{K} 562$ leukaemia cells. The $\mathrm{IC}_{50}$ values were $(186.50 \pm 15.45),(60.35 \pm 16.63),(76.92 \pm$ 11.17) $\mu \mathrm{M}$ for $\mathbf{1}, \mathbf{2}$ and $\mathbf{2 a}$, respectively, and (13.65 \pm 5.51$)$ $\mu \mathrm{g} \mathrm{mL}^{-1}$ for GB. Alkaloid $\mathbf{3}$ was inactive, under the test conditions, indicating again the importance of the sugar moiety when compared with glycoalkaloid 2 . The comparison of significant results obtained for Ehrlich carcinoma and human K562 leukaemia, in 48h cell cultures, is indicated in Figure 1.

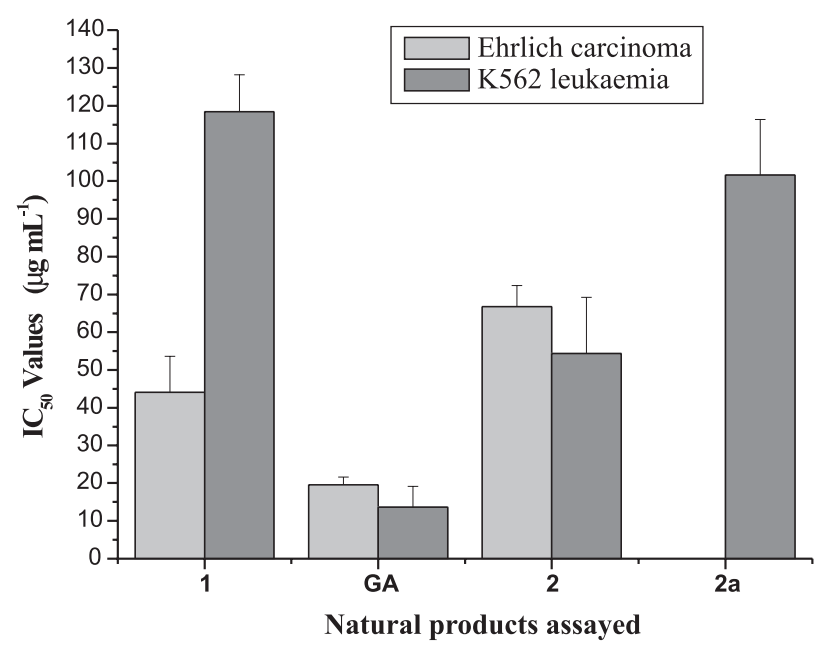

Figure 1. $\mathrm{IC}_{50}$ values $\left(\mathrm{mg} \mathrm{mL}^{-1}\right)$ of 1, 2, 2a and $\mathrm{GB}$ on Ehrlich carcinoma and human K562 leukaemia cultured cell. 


\section{Conclusion}

The results showed that the MTT assay is a useful tool for biomonitoring in phytochemical studies, conveniently providing drug sensitivity information. The genus Solanum includes many native Brazilian species, such as S. crinitum Lam and S. jabrense, which are used in popular medicine and contain flavonoids and glycoalkaloids with potential as leads to new chemotherapeutic agents.

\section{Acknowledgments}

The authors thank to CAPES, CNPq and FAPERJ for financial support, and research $(\mathrm{CNPq})$ and post-graduate fellowships (CAPES and CNPq).

\section{References}

1. Dohadwalla, A. N.; Trends Pharmacol. Sci. 1985, 6, 49.

2. Joyeuw, M. A. L.; Planta Med. 1995, 65, 120.

3. Olatunde, F. E.; Pharmacol. Res. 2000, 42, 75.

4. Caltagirone, S.; Rossi, C.; Pogg, A.; Ranolletiii, F. O.; Natali, P. G.; Brunetti, M.; Alello, P. B.; Int. J. Cancer 2000, 87, 595.

5. Dewick, P. M.; Medicinal Natural Products: A Biosynthetic Approach, John Willey \& Sons Ltda: West Sussex, England, 1998.

6. Rowan, D. D.; Macdonald, P. E.; Skipp, R. A.; Pytochemistry 1983, 22, 2102.

7. Kusano, G.; Takahashi, A.; Sugiyama, K.; Nozol, S.; Chem. Pharm. Bull. 1987, 35, 4862.

8. Alzerreca, A.; Hart, G.; Toxicol. Lett. 1982, 12, 153.

9. Friedman, M.; Rayburn, J. R.; Bantle, J. A.; J. Agric. Food Chem. 1992, 40, 1617.

10. Cham, B. E.; Daunter, B.; Evans, R. A.; Cancer Lett. 1991, 59, 183.

11. Linn, Y. M.; Flavin, M. T.; Schure, R.; Sidwell, R.; Barnard, D. L.; Hofman, J. H.; Kern, E. R.; Planta Med. 1999, 65, 120.

12. Pietta, P. G.; J. Nat. Prod. 2000, 63, 1035.
13. Birt, D. F.; Hendrich, S.; Wang, W.; Pharmacol. Therap. 2001 90, 157.

14. Bravo, L.; Nutr. Ver. 1998, 56, 317.

15. Birt, D. F.; Mitchell, D.; Gold, B.; Pour, P.; Pinch, H. C.; Anticancer Res. 1997, 17, 85.

16. Messina, M.; Deschemaker, K.; Erdman, J. W. Jr.; Amer. Clin. Nutr. 1998, 68, 1329.

17. Grynberg, N. F.; Brioso, P. S. T.; Velandia, J. R.; Echevarria, A.; Carvalho, M. G.; Braz-Filho, R.; Proceedings of the $17^{\text {th }}$ International Cancer Congress, Monduzzi Editore S. p. A. Bologne (Italy), 1998, p. 317-320.

18. Grynberg, N. F.; Carvalho, M. G.; Velandia, J. R.; Oliveira, M. C.; Braz-Filho, R.; Echevarria, A.; Braz. J. Med. Biol. Res. 2002, 35, 819 .

19. Sun, C. M.; Syu, W. J.; Huang, Y. T.; Chen, C. C.; Ou, J. C.; J. Nat. Prod. 1997, 60, 383.

20. Mossman, T.; J. Immunol. Methods 1983, 65, 55.

21. Markaham, K. R.; In Methods in Plant Biochemistry: Flavones, Flavonols and their Glycosides. Harbone, J. B. and Mabry, T. J. eds., Academic Press: New York, 1989, vol. 1, pp. 197-235.

22. Puri, R.; Wong, T. C.; Puri, R. K.; Mag. Res. Chem. 1993, 31, 278.

23. Mahato, S. B.; Sahu, N. P.; Ganduly, A. N.; Kasai, R.; Tanaka, O.; Phytochemistry 1980, 19, 2017.

24. Le Bail, J. C.; Varnat, F.; Nicolas, J. C.; Habrioux, G.; Cancer Lett. 1998, 130, 209.

25. Kandaswami, C.; Perkins, E.; Soloniuk, D. S.; Drzewiecki, G; Middleton, E.; Cancer Lett. 1991, 56, 147.

26. Mitroskotsa, D; Mitaku, S.; Demetzos, C.; Harvala, C.; Mentis, A.; Perez, S.; Planta Med. 1993, 59, 517.

27. Nshimo, C. M.; Pezzuto, J. M.; Kinghorn, A. D.; Farnsworth, W. R.; Int. J. Pharmacog. 1993, 31, 77.

28. Dimas, K.; Demetzoz, C.; Vaos, B.; Marselos, M.; Kobbinopoulos, D.; Leukemia Res. 1999, 23, 1021.

Received: June 28, 2002 Published on the web: December 4, 2002 